\title{
Transitioning policy: co-production of a new strategic framework for energy innovation policy in the Netherlands
}

\author{
René Kemp • Jan Rotmans
}

Published online: 1 November 2009

(C) Springer Science+Business Media, LLC. 2009

\begin{abstract}
This article describes policy-science interactions in a transition process in which we were involved as scientists. We describe the interactions that occurred in a project for the fourth National Environmental Policy Plan in the Netherlands. The project was successful in that it produced a new concept and set of principles for policy to deal with persistent problems such as global climate change, which were used in the national policy plan. The new concept was that of transition and the principles were: policy integration, long-term thinking for short-term action, keeping multiple options open and learning-by-doing and doing-by-learning. Retrospectively, we ask ourselves: what factors facilitated the acceptance of the first ideas about transition management? Reconstructing the events and drawing on interviews with key individuals involved, we have tried to find the key factors for the adoption of the ideas developed in the project. Finally, we reflect upon our role as scientists-advisors and the role of others in the development of a new story line and set of principles for policy. Our own assessment, 8 years later, is that we were engaged in boundary work.
\end{abstract}

Keywords Science-policy coproduction · Boundary work · Transition management

\section{Introduction}

This paper contributes to the literature on joint knowledge production by scientists and policymakers and the wider literature on research utilisation by policy. It describes the co-production of a new strategic framework for policy by policy analysts and policy

R. Kemp · J. Rotmans

Dutch Reseach Institute for Transitions (DRIFT), Rotterdam, Netherlands

e-mail: rotmans@fsw.eur.nl

R. Kemp (ه)

UNU-MERIT, Maastricht, Netherlands

e-mail: r.kemp@maastrichtuniversity.nl

R. Kemp

ICIS, Maastricht, Netherlands 
makers in the Netherlands, called transition management. This article documents the events and interactions that took place in the period March 2000-December 2000 when we worked on a project on transitions and transition management and interacted intensively with Dutch policy makers, especially with civil servants of the interdepartmental working group Energy created for the project 'Transitions and Transition Management'. We will also briefly describe the transition policy developments that took place in the period 20012006 (in which we were less actively involved), and the regained active interactions in 2006-2007.

The article is of interest to those interested in the creation of the transition management framework in the Netherlands and to those interested in co-production of knowledge and policy. It contributes to the literature on science-policy interactions (Weiss 1980, 1991; Jasanoff 1990, 2004; Hoppe 1999, 2002, 2005; Pielke 2004; Eriksson and Sundelius 2005) and the literature on transition management (Rotmans et al. 2000, 2001; Kemp and Loorbach 2006; Kemp et al. 2007; Loorbach 2007; Shove and Walker 2007; Rotmans and Kemp 2008; Smith and Kern 2009). The focus is on the interactions between policy makers/analysts and scientists, how we all learned from each other and to what effect. After other foreign scholars have tried to reconstruct this learning trajectory (e.g. Smith and Kern 2007, Kern and Smith 2008), we found the time was ripe to make a reconstructive attempt ourselves, based on project documentation, participatory observation, interviews with people from policy and science involved in the project and written responses from three insiders.

Our experiences are used to reflect on co-production as a form of boundary work (Gieryn 1983,1995; Hoppe 2005), offering propositions about conditions for productive encounters between science and policy.

\section{Co-production as boundary work}

Scientists and policy makers are generally viewed to live in different words, characterised by different rationalities. In the scientific arena, scientific recognition is an important indicator for success. In the political arena, political power is an important measure of success (c.f. Caplan 1979). Science is highly disciplinary, with outputs evaluated by disciplinary peers. Policy makers do not have disciplinary peers and they are interested in research primarily for the sake of decision-making. Science is more research-oriented than policy which is very much action-oriented, i.e., oriented towards making decisions amidst uncertainty (Hoppe 2002). However, we disagree with the view popular among scientists that science (different from policy) is free of values and interests. As shown by many studies in the sociology of science, scientists are not impartial in their choice of methods, the choice of research topics, the criteria they apply, the framing of issues as problems or solutions, and of course in stating recommendations for policy.

Both worlds, however, which were never fully apart, have evolved. Weingart (1999) claims that the development of the science-policy nexus since the Second World War can be described as a dialectical process of the scientification of politics or policy and the politicization of science (Hoppe 2005). The scientification of politics consists of the increased use of scientific advice by policy makers and policy taking recourse to scientific advice, not just in terms of real use but also by legitimisation of policy through science. The politicization of science refers to political action on the part of scientists in the name of science. This may take various forms. It may consist of a call for policy action or pleas for specific policy actions, for instance the use of carbon trading to deal with the problem of 
global warming. Scientists may be vocal in the public debate and meet with policy makers, in special meetings or workshops. According to Hoppe (2002), the worlds of science and politics increasingly meet, giving rise to boundary traffic.

This boundary traffic-which as shown by Hoppe (2005) and others can take different forms ${ }^{1}$-is evaluated both positively and negatively. The negative view is that science gets distorted and loses credibility: "If scientists evaluate the research findings of their peers on the basis of their political perspectives, then "scientific" debate among academics risks simply becoming political debate in the guise of science" (Pielke 2004, p. 28). The politicization of science by scientists is said to threaten the development of effective policies in contested issues and more fundamentally may present a threat to the institutions of science and democracy (Pielke 2004, p. 31).

The positive view says that interactions between policy makers are beneficial for stimulating mutual learning: scientists learning about aspects relevant for policy and policy makers learning to see things in new, different perspective. The dialogue between scientists and policy makers may result in discourse coalition that shares the usage of a particular set of story lines over a particular period of time (Hajer 1995). Such coalitions are institutional vehicles for change: “...storylines play a key role in the positioning of subjects and structures. Political change may therefore well take place through the emergence of new storylines that re-order understandings. "Finding the appropriate storyline becomes an important form of agency" (Hajer 1995, p. 56, our italics). Indeed, this is what happened in the case discussed here: in the NEPP4 project a new story line was created, which obtained significance as a "boundary object" (Star and Griesemer 1989): a concept shared by different communities but viewed or used differently by each of them. Around the story line, a discourse coalition formed of actors using the term transition but holding different interpretations of what it meant and implied for policy.

In the project, there is the co-production of knowledge as a collaborative effort of scientists and policy makers. Over and above the project, there is the co-production of knowledge and social order (Jasanoff 2004). ${ }^{2}$ We opt to focus on the issue of co-production of knowledge rather than the co-production of knowledge and social order. We conceptualise the co-production of knowledge as boundary work. The term 'boundary work' refers to the way in which actors construct a social boundary around 'science' (Gieryn 1983 , p. 782). In order to gain and keep credibility, legitimacy, and authority for the scientific practice, scientists demarcate science from other practices such as religion or politics. But boundaries may be blurred deliberately to facilitate boundary crossing and bridge-building (Gieryn 1995).

Before presenting our results we discuss the methodological approach used in the research that culminated in this paper. Normally policy interactions of knowledge integration and bargaining are being assessed by analysts who themselves were not involved in the interactions. Their reconstruction is an outsider-reconstruction, usually based on indepth interviews, readings of relevant documents and scrutinising other analyses. In so doing they are guided by theoretical assumptions, research questions and ontological

\footnotetext{
${ }^{1}$ Hoppe (2005) distinguishes five types of boundary arrangements: enlightenment model, technocracy model (models in which primacy is with science), bureaucratic model (primacy of politics) and dialoguebased models.

2 In the latter tradition, "co-production is shorthand for the proposition that the ways in which we know and represent the world (both nature and society) are inseparable from the way in which we choose to live in it" (Jasanoff 2004, p. 2). This tradition of Science, Technology, Society studies is interested in how science and social order constitute each other, where "science (...) is understood as neither a simple reflection of the truth about nature nor an epiphenomenon of social and political interests" (ibid, p. 3).
} 
views. Our approach is different because we ourselves were involved in the process as scientists/policy advisors, which has the advantage that we have a detailed view of what happened certainly as far as our own actions and considerations are concerned. This enables a reconstruction of the interaction with policy makers that is based on participatory observation, on our own project documentation and of course a first-hand view on what we did in terms of giving presentations, handling criticism and dealing with policy demands. At the same time, we acknowledge that a certain distance is required and that there is a risk of overstating our own role and that we may have been blind to particular things that were seen by others.

We therefore validated our own impressions and assumptions in various ways. We interviewed two key individuals from Dutch government, Peter Aubert and Frans Vollenbroek $^{3}$ and made use of interviews with other relevant policy makers done earlier in the process. We also interacted with Rob Hoppe, an expert in boundary work, to interpret the boundary traffic in theoretical terms. This all provided us with useful feedback on the co-production process and on our own role and that of others involved.

Describing and interpreting co-production processes is notoriously difficult, if only because people's interpretations of it differ. Nevertheless, we hope we have given an adequate account of the policy-science interactions by drawing on multiple sources, involving a rather detailed chronological account of events, something which has not been done before.

\section{The project on transitions and transition management}

In a letter dated May 1, 2000, the Directorate Strategy and Planning of VROM (The Ministry of Housing, Spatial Planning and the Environment) officially asked Jan Rotmans of ICIS to tender for a study on transitions and transition management. The request for making a bid for a tender was after a presentation of Jan Rotmans at VROM on March 17, 2000, in which he focused on the concept of transitions. ${ }^{4}$ The notion of transition had come up as a potentially relevant concept to the 4th National Environmental Policy Plan (NEPP4). The first National Environmental Policy Plan appeared in 1989, the second in 1993 and the third in 1998. Because NEPP3, in which decoupling of environmental degradation from economic growth was a key issue, appeared during the election period in the Netherlands, some far-reaching choices were postponed. This together with the emergence of persistent problems, such as climate change and loss of biodiversity, created a demand for a new overarching concept and a new vocabulary for persistent problems. The focus on persistent problems and a longer time horizon fitted within a larger context of ecological modernization, liberalization and privatization and earlier Dutch attempts to deal with long-term ecological complexity such as DTO (Sustainable Technological Development programme) and NIDO (National Initiative for Sustainable Development). This paved the way for increasing the attention for the notion of transition, which was seen

\footnotetext{
3 Peter Aubert was the head of the project team dealing with long-term energy issues for the Ministry of Economic Affairs (EZ). Frans Vollenbroek was strategist at the Ministry of Environment (VROM). They acted as important spokespersons and ambassadors for transition thinking. Peter Aubert was managing the project implementation of transition management (PIT) in the Ministry of Economic Affairs.

4 The lecture was after a lecture 2 weeks earlier about sustainable development at VROM. Cees Moons the project leader of the NEPP4 working at VROM attended this lecture and when the term transition was used, he told Jan Rotmans that he was interested in transition processes and invited him to give a talk about transitions.
} 
as potentially promising and useful in this regard. But before it was accepted for use, the NEPP4-team wanted to learn more about the concept of transitions and the possibilities for managing transitions.

Rotmans was asked to cooperate with René Kemp working at MERIT, ${ }^{5}$ based also in Maastricht. The project was the second project funded by VROM on transitions. ${ }^{6}$ The project was for the NEPP4 and had to be done in less than 4 months time. The official end date of the project was September 1, 2000, but in reality the project ended by December 2000. The results were to be of use to the NEPP4 and for doing so, the project was to address questions on transition management and outline further research on the transition to a sustainable energy supply system.

The tender by ICIS-MERIT promised to do three things:

1. To delineate (deepen) the transition concept, both in a general sense and specifically for the transition to a low-emissions energy supply system.

2. To explore possibilities for transition management in terms of managing multi-actor processes and framing conditions.

3. To come up with recommendations for further research on the energy transition.

The ICIS-MERIT was selected for funding but we were asked to revise the proposal. The proposal initially was viewed as too academic. To increase the relevance for policy, we were asked to organize an extra workshop in June with policy makers and to discuss our ideas about transition management with top civil servants in special interviews as a part of the project, so as to secure and create support for transition management the principles of which had to be developed. ${ }^{7}$ Our project was thus expected to produce insights about the "manageability" of sustainability transitions and to scrutinise scientifically the topic of transition employed in previous studies: VROM-Raad (1998), te Riele et al. (2000), KETI 2000).

On May 22, we submitted a revised proposal (with a total budget of $83 \mathrm{k}$ euro), which was approved and on May 29, we had a first project meeting among ourselves. The ICISMERIT team consisted of four persons: Jan Rotmans (project leader), Marjolein van Asselt, Kirsten Molendijk (from ICIS) and René Kemp from MERIT. At this meeting, a project plan was made. One month later, on June 27, we had a first important meeting, with energy experts.

At the meeting with energy experts we presented our first ideas about transitions and discussed issues of sustainable energy. This meeting did not go smoothly. The usefulness of the transition concept was openly doubted by the energy experts. Wim Turkenburg, a leading energy expert and member of the influential VROM-advisory council found the concept of transition merely fashionable and not new. We had useful discussions about various topics, such as transition goals, the issue of scale, in particular the international dimension, and the choice between centralized versus decentralized systems. It was noted that the energy system already was in a transitional stage, as a result of the ongoing privatization and liberalization and the emergence of renewables. The meeting did not end

\footnotetext{
5 MERIT is the Maastricht Economic Research Institute on innovation and Technology (now UNU-MERIT).

6 The first project (by Harry te Riele) was based on a flux model of change which was applied to two empirical cases (the Aramis public transport systems in France and biological argiculture). It did not go into issues of steering, except for offering the suggestion that interventions by the right people at the right time could have big impacts in terms of achieving a transition (Te Riele et al. 2000).

${ }^{7}$ Bridges for crossing the boundary were thus built into the project infrastructure already from the start, at the special request of policymakers.
} 
in a consolidated, converging view on transition and transition management. Sensing the scepticism of the energy experts, Sylvie Warmerdam, the project officer from VROM in charge of the project got concerned about the project. In a crucial meeting, Jan Rotmans put her on the spot by arguing that unless we were allowed to follow our own research methodology and approach, we would stop working with them. This was meant to create more degrees of freedom in the project to follow our own research route as sketched out in the work plan.

As a result, the project was not aborted (there was actually no real alternative for the VROM civil servants to start up an alternative project), and we were allowed to continue our work, and on July 7, we had a meeting with the interdepartmental working group set up for our project. In the morning, we presented our definition of transition together with the results of the meeting with the energy experts and our first ideas about transition management. At the meeting, we had intense discussions in which the representative of the Ministry of Economic Affairs, Peter Aubert, openly challenged us and questioned our scientific authority.

On July 10, a background report was delivered by Frank Geels and René Kemp about socio-technical transitions offering empirical evidence. This was the first of two background papers. ${ }^{8}$ In total we had four empirical cases, only one of which consisted of a "managed" transition: the transition from coal to natural gas in the Netherlands.

On July 7, we had a workshop with the working group and the NEPP4 team in The Hague. At this meeting, we discussed the report of Geels and Kemp (2000) and a scenario study of ECN (Energy Centrum Nederland, an energy research centre). This time discussions were more constructive, perhaps because now empirical evidence was being discussed.

On July 27, Paul van Slobbe from EZ and Sylvie Warmerdam from VROM came to Maastricht to discuss the first drafts of the chapters about transitions and transition management. They asked us to clarify the need for end images (transition goals) and to pay more attention to actors in the transitions described in the report of Geels and Kemp. We were also asked to delineate questions for research and issues for policy. They wanted a few "what to do's" in the report to increase the policy salience.

On August 21, Job van den Bergh, a consultant from DHV hired by VROM for the NEPP4 project, came to Maastricht to discuss the agenda for the meetings on August 25 and 31.

The meeting on August 25 was a meeting with the working group on energy. This meeting was meant to prepare for the final meeting on August 31, about transitions and transition management, at which our findings would be discussed among a broader group. At the meeting in Maastricht, we jointly determined the agenda.

The preparatory meeting on August 25 went well. Feelings of doubt had largely gone. Transition management was now considered as a useful concept for long-term policy, offering a new perspective for addressing persistent problems. People agreed on the need for transition management, the details of which were still to be worked out. In response to the quite positive reception, Jan Rotmans said that TM is not a panacea for persistent

\footnotetext{
8 The second paper on government policy and energy transitions came out on August 16 (Verbong 2000). It was written by Geert Verbong, associate professor at the Technical University of Eindhoven (TU/e). Verbong was an energy historian who had written a book about the history of alternative energy in the Netherlands.

9 The other transitions were: the transition from steam engines to electro motors to provide motive power in the manufacturing sector (1850-1920), the transition from sailing ships to steam boats (1780-1890) and the demographic transition.
} 
problems, neither is it an easy thing to do. Of the people present, only Frans Vlieg of VROM remained critical. Having discussed our ideas with policy makers at different occasions, we were able at this moment to effectively explain the essentials of transitions and explain the key aspects of transition management. The basic story line was that persistent problems needed fundamental system changes, which could only come about if societal actors are mobilised and if the playing field is kept wide. The story line was based on a distinction between system improvement and system innovation, which was applied to the Dutch energy supply system. Figure 1 effectively illustrated this distinction.

In terms of policy, we argued that for achieving a transition to a low-emission energy system, transition management would:

- comprise Kyoto-policy but not be limited to it;

- not make a choice for any of the three systems options for reducing $\mathrm{CO}_{2}$ emissions by $50 \%$ as formulated by ECN (Energy Centre Netherlands), status quo, hydrogen, electric society;

- not go for an upheaval of the energy system in the short term;

- mobilise societal actors for taking action towards long-term structural change;

- involve additional research for innovative solutions;

- support innovative experiments with new energy carriers at the local and regional level.

Our conclusion that so far policy had been too much focused on system improvement rather than on system innovation was acknowledged by the interdepartmental working group. It also corresponded with the criticism of the VROM-Raad (1998) in their advice "transition to a low carbon energy supply" (in Dutch), who recommended to make a start with a Dutch system of tradable emission permits.

On August 31, we had the second and final meeting with the project team and the NEPP4 team. We met for a whole day in The Hague. In the morning, there were three presentations by the ICIS-MERIT team, one about the transition concept, one about transition management, and one about the implications for policy. After the last presentation, people were divided into two groups to discuss transition issues. The first group consisted of people with a general policy background. This group was asked to discuss transition management ideas more generally with people from ICIS-MERIT. The second subgroup was asked to discuss transition management issues for the case of the emissionlow energy supply. People present were given a card which described the essentials of transition management, in the form of five rules of thumb:

- Long-term thinking as the basis for short term policy

- Think in terms of multiple domains (multi-domain), different actors (multi-actor) and different levels (multi-level)

- Learning as an important aim for policy ("learning-by-doing" and "doing-bylearning")

- Orient policy towards system innovation besides system improvement

- Keeping options open (wide playing field).

The idea of the rules of thumb came from policy people, in particular from Cees Moons, leader of the NEPP4-project. He asked us to come up with a set of key principles covering transition management. In the first instance, we refused to do this and a meaty discussion arose among the NEPP4-team and ourselves. Whereas the policy makers wanted to reduce the complexity of transition management to easily digestible chunks, we argued that there are no simple do's for transition management, in order to avoid any implied suggestion of social engineering, blueprint thinking and planning. Giving in to the demand from policy 


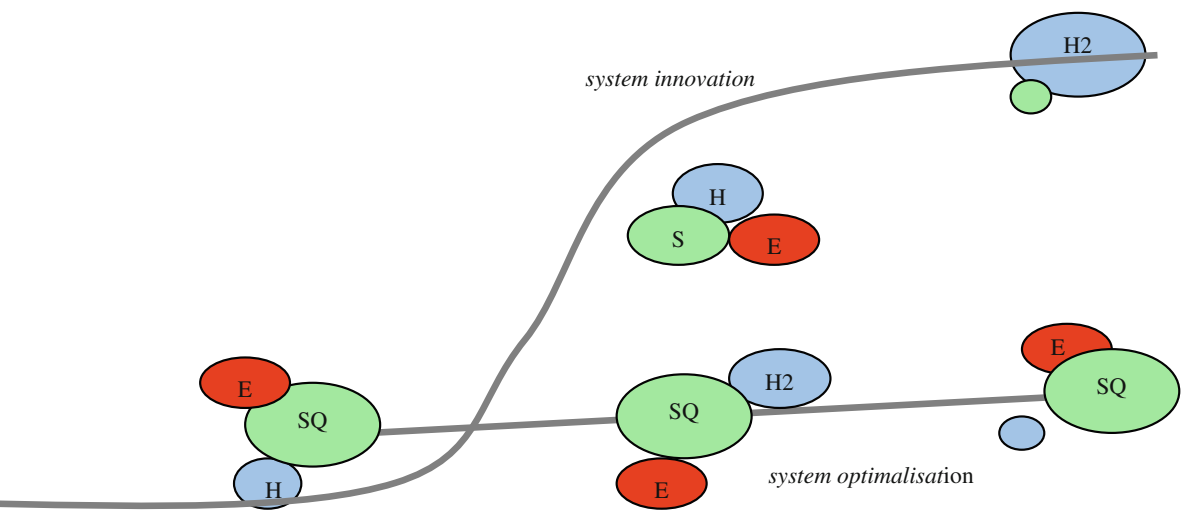

Legend: $\mathrm{SQ}$ = status quo, $\mathrm{H} 2$ = hydrogen, $\mathrm{E}$ = electric society

Fig. 1 The visualisation of system innovation and improvement trajectories for energy supply. $S Q$ status quo, $\mathrm{H}_{2}$ hydrogen, $\mathrm{E}$ electric society

we then presented a set of 10 starting points (signposts), which was still considered too complex by the NEPP4-team. In the next iteration, we presented five starting points, leaving off aspects as envisioning, intermediate goals, communication and negotiation, innovation network, and support. Then in the final iteration, the five starting points were reformulated in more accessible language (replacing, for e.g., 'exploring multiple transition paths' by 'keeping options open') which lead to the rules of thumb formulated above. The rules of thumb played an important role in communicating the concept of transition management to a wider policy audience. However, they were not directly used in the political process to defer difficult political choices as suggested by Meadowcroft (2005). During the process, we emphasized the reflexive aspects of transition management: searching, learning and experimenting, goal-searching rather than goal-led. The policy makers on the other hand, emphasized the practical usefulness in a policy environment with its own currency and own life cycle. We argued that transition management offered a framework for the choice of instruments and institutional arrangements, putting policy choices in a different perspective. The policy makers argued that they needed policy principles that could be used directly in the policy process in order to 'sell' transition to other, more sceptical colleagues.

Figure 2 shows a number of the original signposts divided over the several stages of a transition.

A key element of transition management was the long-term orientation through quality images, chosen by society, as a kind of compass for policy-making. ${ }^{10}$ The quality images to be achieved represented ambitions and comprised various options (they could not be met through a single technology). They had to be inspiring (such as ,putting a man on the moon") and would be different from normal policy goals such as a reduction of GHG emissions by $\mathrm{x} \%$. The long-term was chosen to mean one generation or more (25 to 50 years). Crucial was also the metaphor of "basket of images" (as suggested by the policy makers), indicating that the transition goal encompasses multiple images, which are not

${ }^{10}$ Details of how they were to be chosen by society were not worked out; we only felt that the choice should not be made by typical experts. 


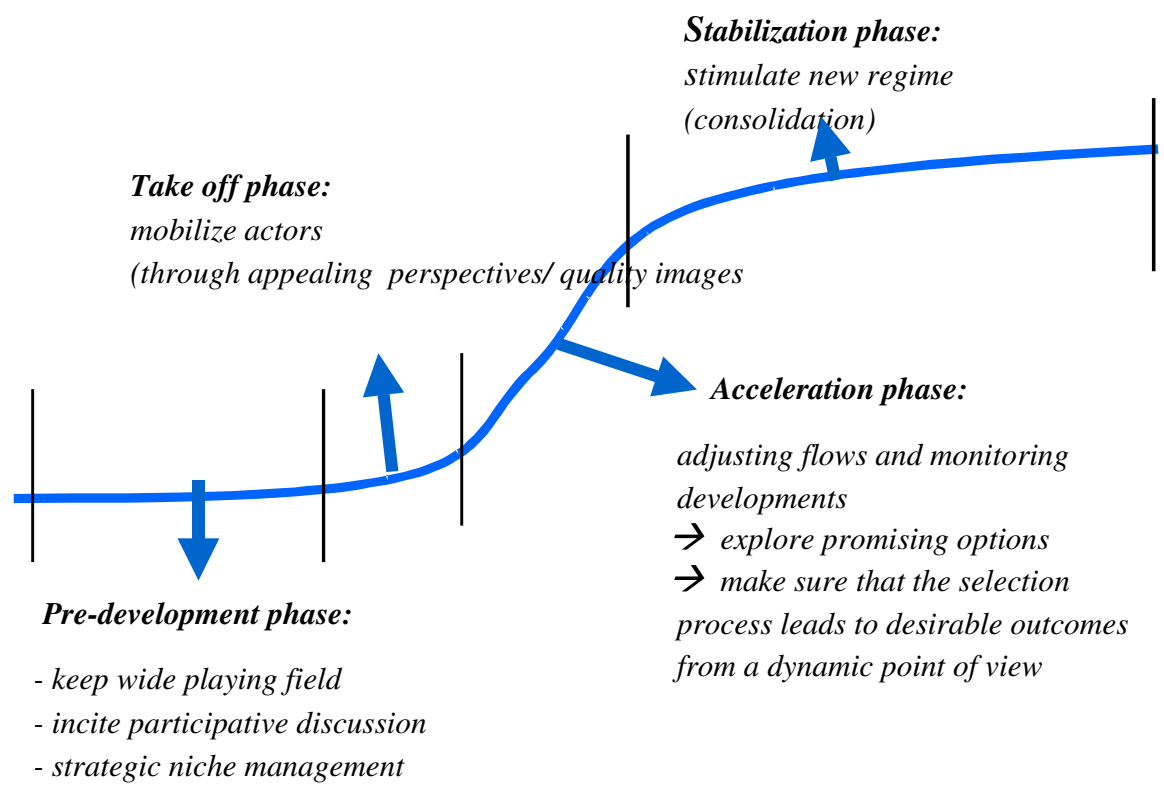

Fig. 2 Different policy principles of transition management in different stages of the transition

only technological but also social and which may be adjusted over time as a result of social learning. The transition images contain multiple options and are qualitative rather than quantitative by nature. The transition goal is in fact a basket of goals informed by the visions of those participating.

Both in the break-out groups and the plenary discussion, the wideness of the playing field and the need for transition experiments was a recurring topic. There was concern that the playing field was not wide enough and that the energy policy was too much focussed on technology. It was broadly shared that policy should target business companies that want to do something novel helping us to learn about system innovation. Several concrete suggestions were offered by the policy makers for what government could or should do. It was suggested that government should be more like venture capitalists and should orient its policy towards niche actors. In innovation policy, more attention was to be given to learning about social and cultural factors as this was not actively promoted through policy. Most experiments were demonstration projects, aimed at proving success instead of being oriented at learning. Instead of being concerned with short-term outcomes, policy had to be more concerned with dynamics and stepping stones.

At the plenary discussion led by consultant Job van den Bergh, key policy officials who had been part of the project and had received the concept report on transitions and transition management, were asked to come up with statements. The first to speak was Cees Moons the leader of the NEPP4 project. Moons said that he found the transition perspective useful for policy and that government had to be more concerned with institutional change and argued for market creation policies. Hugo Brouwer, who was later to become the director of the energy transition process, said he liked the transition draft report and agreed with the need of anticipating transformative change processes and making sure that the playing field was wide enough. 
End of October 2000, we produced the final report. The report contained figures we had used during presentations. It contained a clear-cut message that a transition approach was worthwhile. Project researcher Marjolein van Asselt of ICIS went to work for VROM for a few months, to work on transition management and related topics.

A series of follow-up meetings was organized with other stakeholders to broaden the support for transition management. On November 6, there was a transition exploration meeting in Utrecht, involving researchers (from ECN, RIVM and TNO, three important research organisations) and policy officials. Transition management ideas were presented by the NEPP4 team.

The RMNO organized a workshop at the beginning of 2001. This was a meeting for scientists and policy advisors, where some participants were asked to critically reflect upon the transition report. Jeroen van den Bergh, a Dutch reputable environmental economist, emphasized the missing link with macro economic theory. But overall, the concepts of transition and transition management were again well-received. Various participatory formats were used to test out the transition idea and principles of transition management among a wider policy audience. One format was the "Lagerhuisdebat" (a popular Dutch television programme), mimicking the format of the House of Commons, with one part of the audience being pro transition management and the other part being against it. After half an hour of discussion people were asked to change camps, and argue the other way. Another format was the telling of fairy tale about transition management in a meeting with policy makers/analysts. ${ }^{11}$ The idea was to play around with an abstract concept like transition management in a playful manner, to frame the minds of policy makers. Most of these creative participatory settings were thought of by policy makers, while we took part in the performance.

A crucial event was the "Heath-session" of 5-7 March, 2001 organized by VROM to discuss the essence of NEPP4, and the supposedly central role of transition management within it, with the responsible minister of environment, Jan Pronk. At first instance, Jan Pronk was opposed to using it; he was more in favour of using the concept of ecological footprint as a central concept for environmental policy-making. But some key players, such as Cees Moons, could convince him of the usefulness of the transition concept. After this meeting, the transition and transition management concept were chosen as central concepts of NEPP4.

\section{Transition management activities by the Dutch Government 2001-2008}

In 2001, the transition approach was officially accepted by the Dutch government: transition policy for sustainable energy (NMP-4 2001). Minister Pronk, responsible for environmental issues, allowed it to be a central concept in the longer term environmental policy of the Netherlands. The Ministry of Economic Affairs (EZ) took over a great deal of the principles of transition management; they set out to support the creation of transition coalitions and created a special instrument for transition experiments. They called it the transition approach and abandoned the term management, which had too much the connotation of command-and-control (with the government being in the lead): they wanted to be seen as facilitator rather than manager. It took a long term orientation (50 years) as a starting point and adopted a strategy of keeping options open for a certain time. It created arenas (platforms), developed a multitude of transition pathways and started up about 100

11 The fairy tale on transition management was presented by Marjolein van Asselt of ICIS. 
experiments. Here, we cannot give a full account of Dutch transition policy. For that we refer to Ministry of Economic Affairs (EZ) (2001, 2003a, b, 2004), Loorbach (2007), Kemp and Loorbach (2005), Loorbach and Kemp (2008) and Kern and Smith (2008). We will only highlight the institutional cornerstones of Dutch transition policy in chronological order since 2001.

First, the creation of seven transition platforms (arenas) by the Ministry of Economic Affairs (EZ) around themes like sustainable mobility, built environment, sustainable electricity and the energy-supplying greenhouse. Around these platforms, a broad involvement of stakeholders was created, based on the development of transition visions, pathways and experiments. The platforms functioned autonomously and were usually led by business people. Next to business people, also frontrunners from government, NGOs, intermediaries and knowledge institutions were present (Loorbach 2007; Kern and Smith 2008).

Second, the creation of the "Unieke Kansen Regeling" (UKR), a 35 million Euro arrangement for transition experiments. To be eligible for support the experiments had to (1) be a part of an official transition path, (2) involve stakeholders in an important way and (3) have explicit learning goals for each of the actors of the consortium. Between 2004 and 2007, 160 million euro was spent on transition experiments through the UKR and the EOS-DEMO programme (Ministery of Economic Affairs (EZ) 2008).

Third, the creation of a Frontrunners Desk (FD), a government service point which is meant to service frontrunners, initiators of experiments and transition-related activities. The Desk was important for helping small business enterprises and to engage them more actively in the energy transition process.

Fourth, the establishment of the Taskforce Energy Transition. The Taskforce, led by Rein Willems (CEO of Shell Netherlands) and created in 2005, was a strategic group of around 15 high-level representatives from science, business, NGOs and government and was given the assignment to reflect upon the over-all process of the energy transition, define a shared direction and stimulate in general the further development of the energy transition. The Taskforce collected the transition paths and experiments of the different platforms and combined these with a scenario-study on future developments in energy-production and consumption into the over-all 'Transition Action Plan' (TAP) (Task Force Energietransitie (TFE) 2006). In the TAP, the taskforce made a plea for consistent energy policies that transcend political trends and for a substantial increase in government investments in sustainable energy (from 1 billion euro to 2 billion euro per year). The taskforce was ended by 2007 but was followed up by a similar body, the Energie Regieraad in April 2008.

Fifth, the creation of the Interdepartmental Project directorate Energy transition (IPE) in 2005. In the IPE government, officials from six different ministries concerned with sustainability transitions in respective domains (energy, agriculture, biodiversity, mobility, water, construction) together reflect upon the transition process and its outcomes with two goals: to better facilitate and govern the energy transition process and to innovate policy and government institutions in line with the requirements of the transition approach. The establishment of the IPE itself is considered to be a novelty in energy policy, since it included policy officials from a range of ministries, from environment to transport and from foreign affairs to finance. This arose from experiences within the process that indicated a lack of coherence, innovation and learning at the strategic policy level. A better cooperation between EZ and VROM has been established. ${ }^{12}$

12 As an anecdote, Frans Vollenbroek recalls Belgium people saying: "we really envy you: you have brought down the walls [between departments], in our country we are fighting each other to death". 
We were not directly involved in the energy transition process since 2001. Although there were regular interactions, they took place on an ad hoc basis. Official interactions were resumed by 2006 when Jan Rotmans was asked to start a reflection process, with the aim to reflect upon the first 5 years of the energy transition process. This included a critical review of the whole process according to the principles of transition management, training services to the administrative managers of the platforms and concrete recommendations for the next 5 years.

\section{Reflecting upon the co-production process}

In this section, we reflect on the outcomes and process of interactions. What did the coproduction process within the transition context achieve? That is a relevant question which is not easy to answer. Reflecting upon the intricate, largely unstructured but interesting and intense co-production process requires a certain distance. By now, we can ascertain that the indirect, intangible results of the co-production were at least as important as the direct, concrete results. Perhaps the most important result was the emergence of a new language as communication vehicle in a new discourse, which evoked a new élan. The transition language consisted of notions as multi-phase, multi-level, niches, frontrunners, regime, regime-players, keeping options open, learning-by-doing and doing-by-learning, arenas, multi-actor, basket of images (see Fig. 3), transition patterns and pathways, transition experiments, etc. While the 'technical' language came from us (e.g. multi-phase, multilevel, niches, regime), the 'social' language was created in meetings with policy makers (e.g. frontrunners, basket of images, learning-by-doing and doing-by-learning). The transition language had a bridging function between the scientists and policy-makers involved. The role of rather simple transition concepts cannot be underestimated: in particular the multi-phase and multi-level concepts turned out to have a great communicative value. Both the transition language and transition concepts helped to stimulate integrated thinking ('as well-as' rather than 'either-or'). In our assessment, the new discourse paved the way for a new long-term energy policy in the Netherlands, which received a new impetus and aimed at a much higher ambition level and sustainability goals than before. Both the language and discourse were shared with others outside the policy circles and entered new networks and coalitions formed as part of the energy transition process. ${ }^{13}$

Another important result was the long-term orientation that resulted from the envisioning process. A shared perspective on a sustainable energy supply system in 2050 in the Netherlands was formulated as: (a) clean, i.e. a $\mathrm{CO}_{2}$-reduction of 50\%; (b) affordable (low prices); and (c) secure (guaranteed and reliable supplies and provision of energy services). This was supplemented by more specific goals such as the goal to increase the annual rate of energy savings from 1.5 to $2 \%$ a year and the target of $30 \%$ for green energy sources by 2030. The goals came from discussions with the energy transition platforms.

A strategic transition agenda was created, as a third result: an agenda of reform that contained longer-term and medium-term goals, multiple pathways onto the sustainable energy vision and a first series of small-scale transition experiments around the pathways to explore a range of future possible energy options. Renewed trust among parties involved

\footnotetext{
13 It also entered the mind of people in domains of mobility, water management, and biodiversity and sustainable management of resources, but in those areas, it did not become a hegemonic concept (Loorbach 2007).
} 
Fig. 3 Final goal as "basket of final images"

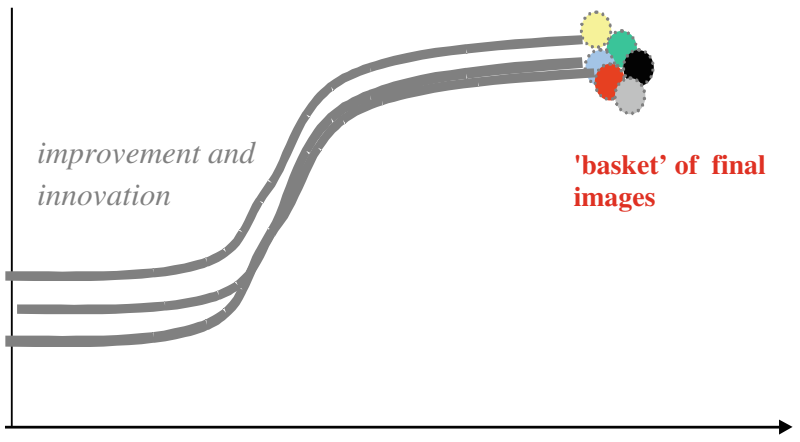

in this transition trajectory was important. Also renewed trust in government was created, as a trustful partner of business. ${ }^{14}$

From the interactions, there emerged a story line about the need for policy to be concerned with long-term transformative change which was articulated by the new discourse coalition. This is also what Smith and Kern (2009) have found: the transition storyline broadened the policy focus beyond firm-level processes of cleaner technology and improved environmental management.

Reflecting upon our role within the co-production process, we can distinguish various roles. We played a partisan role as scientists, not in the sense of distorting science but in putting forward our preliminary ideas about transition management. We also used our skills in persuasion. The concepts that we used were not neutral devices. The upwardbending S-curve has a suggestion of uplifting, which helped to create a positive image around system innovation. We also acted as co-developers. We started the co-production process with only a rough idea on transition management. The whole process offered us the opportunity to co-develop ideas in interaction with policy makers. While we offered simple transition (management) concepts, the policy makers delivered salient policy issues such as possibilities (and limitations) for steering and the relationship with existing, short- and medium-term policy.

In a late stage of the co-production process, we had in-depth interviews with three senior civil servants (Cees Moons, Hugo Brouwer and Jip lenstra), which delivered us interesting feedback and created also some collective ownership. Cees Moons emphasized the importance of a more actor-oriented approach (rather than a systems-based approach), Hugo Brouwer advised us to exploit differences in acceptance and Jip Lenstra gave examples of how we could utilise societal dynamics. These insightful statements influenced our way of thinking and co-determined the transition analysis. We used quotes from them in the final report.

While we acted as advocates for a transition approach, we emphasized that the concept of transition management as developed in the project for NEPP4 was not yet mature enough for using it in day-to-day practice. Here we played the traditional, critical role of scientists acknowledging the limits of our knowledge. We felt that the further development of transition management would require more theoretical research rooted in complex systems theory and new forms of governance and more, diverse empirical research. Nevertheless, the policy makers involved wanted to use transition management immediately and they started with developing transition policy as a shadow trajectory within the

$\overline{14}$ This was a precarious process, in which trust was gradually build (see Sect. 6). 
ministries of environment (VROM) and economic affairs (EZ). This is evidence of policy makers' action perspective and desire to be in command. Peter Aubert was very open about him not wanting us to be involved in the implementation of the transition policies in the Ministry. He openly said when the project was over: from now on we will deal with it ourselves.

Policy makers were thus involved in theoretical discussions, the interpretation of historical evidence and in co-determining the issues for discussion. They also stimulated us to do particular things; such as to come up with rules of thumb and to discuss transition ideas with senior policy officials. In terms of the typology of Hoppe of the two models that come closest to our experiences - the learning model and the advocacy model—we think that the advocacy model resembles the interactions best: we ourselves acted as advocates, the policy people had views and policy positions playing a role, and collectively in a process of deliberation, fed by empirical research, we jointly produced a story line. This fits with the dispositional variant of the advocacy model which "posits a discourse-structuration and interaction concept of knowledge use" where "science-advisors and policy actors in their interactions jointly shape political discourse around a central analogy, a story line (Hajer 1995), a concept representing a particular problem definition, or a rhetorical style (Hood 1998)" (From Hoppe 2005, p. 211). This is in line with Smith and Kern (2009) who argue that transition management can best be conceptualized as a discourse coalition.

From a boundary work perspective, it is interesting to look more deeply into four questions: Were we producing science? Were we seen as scientists? Did everyone understand the transition story line in the same way? How new was the transition story line?

As to the first question, were we producing science, we would like to say the following. In our own mind, we were engaged in analysis and the production of policy advice, whether one calls this science is a matter of perspective. ${ }^{15}$ The concept of transition and the multilevel perspective were seen as scientific, by us but also by the others involved, without us resorting to claims that this was science and to be accepted as such. The principles of transition management were viewed useful from the point of view of policy. Were we seen as scientists? Yes, we were seen as scientists, coming from a different world, the world of science. On this point, Peter Aubert says the following:

We had a great deal of respect for you, as outsiders to the policy world; in particular, we valued your ability to make historical connections which were new and exciting, and your ability to translate elements in a new policy approach. At the same time, your status as outsider was a handicap, we discovered that both of you did not know a great deal about energy innovation and energy policy. For this we had to turn to ECN [a Dutch energy research institute].

This shows that we were valued as "intelligent outsiders" bringing new concepts to the policy realm. For Frans Vollenbroek, a policy official with a previous career in research, it was irrelevant whether we were scientists. For him, it did not give us special status. For Peter Aubert, however, it was important that it was coming from scientists and was backed by "science".

\footnotetext{
15 Whether something is science or not is a demarcation issue. Essentialist criteria of science being concerned with truth finding and 'right' classifications have been proven as inconsistent and ambiguous by constructivist analysis (Gieryn 1995). Facts are theory laden, and scientists adhere to the use of particular methods, theories, standards and evaluation points (such as the Pareto criterion and rationalist assumption in the case of economics).
} 


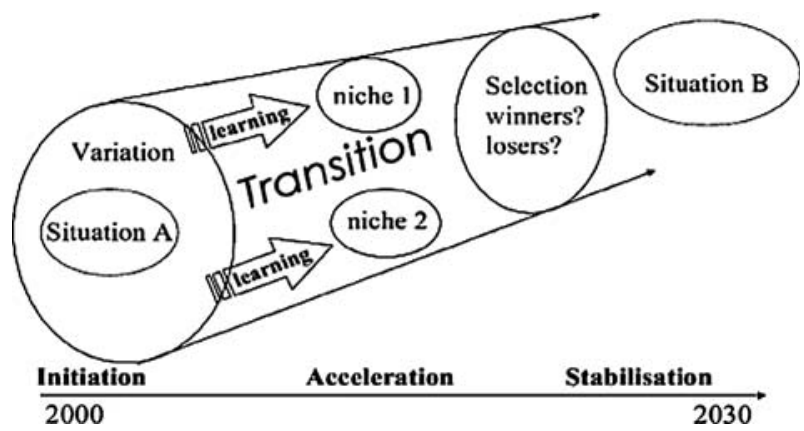

Fig. 4 Transition process as conceptualized in the KETI project

Did everyone understand the transition storyline in the same way? The answer probably is no (story lines as meta-narratives are never understood in the same way, Hajer 1995), but we have no firm evidence about this. As to way in which transition management was used, we obviously noticed quickly that certain elements of what we had proposed were not used by policy makers. Peter Aubert is open about him taking things in a selective (partisan) way:

In a certain sense, the talks were 'negotiations' about the new jargon to use, it helped me to identify which buzzwords would work, and which ones would not work. I think it really worked like that - if I did not understand something, or found it too farfetched (too theoretical), I would not use it. In my view this helped to secure "acceptance" for the transition issue. ${ }^{16}$

How new was the transition story line? For Peter Aubert (Ministry of Economic Affairs), the transition story line and underlying principles were new, for Frans Vollenbroek from the Ministry of Environmental Affairs transition thinking as such was not entirely new. As a member of KETI (an ad-hoc working group of policy officials discussing issues of knowledge and technological innovation), he and others in the group had been thinking already in terms of a long-term transition perspective, as is shown by the following graph from the KETI-report from 2000 (Fig. 4).

According to Vollenbroek, the KETI report built on insights developed in the DTO programme, the ideas of Henk Diepenmaat about actor management and the project of Harry te Riele cum suis on transitions in 1999. Frans Vollenbroek also notes his own role in bringing transition ideas to his superiors. Although the potential of the transition concept was already explored within the KETI-group, they struggled with translating the concept into 'management' rules for system innovation. That was, according to Aubert and Vollenbroek, the step we made in the co-production process.

From the above discussion, it is clear that the concept of transition functioned as a "boundary object" (Star and Griesemer 1989) or "boundary concept" (Metze 2007) for scientists and policy makers alike, allowing for boundary traffic (Hoppe 2005). A boundary concept, according to Metze (2007) consists of "mixed metaphors, discursive devices [that] blur boundaries and with that align different and possibly conflicting discourses and practices" (Metze 2007, p. 10). In our project, traditional boundaries of science and policy

${ }^{16}$ He also confirmed what we suspected at the time: that in meetings with us at times he would play the role of "devil's advocate" by asking challenging questions. 
were temporarily lifted, not by explicit choice but through the type of interactions that we had: the open discussion format and the stake of producing something useful for policy. The frequent interactions with policy makers helped us to get a clearer idea of policy concerns and constraints and helped the policy makers to explore the potential usefulness of 'managing' transition processes. The open and critical discussions facilitated mutual learning and helped to create a common ownership of the transition management concept.

In retrospect, we can see that we played various roles, from co-developers to critical reflectors on policy. We co-developed with policy makers the first rules of transition management and co-created a language for policy usage of the concept. We offered data in the form of case histories and critically reflected on oversimplified and direct usage of transition management in the policy context. Of the two advocacy models of sciencepolicy interaction distinguished by Hoppe (2005), adversary and dispositional, we would say that the dispositional model approximates the interactions best. The dispositional model posits "a discourse-structuration and interaction concept of knowledge use". Even though the outcome was convergent learning, the process was not a 'socratic' learning process. We acted as advocates and the policy people took what they liked and wanted. Looking at the primacy element which is central to the scheme of Hoppe, the primacy did not lay with us or with the policy makers. Primacy is a difficult concept to apply in our case, it is more meaningful to talk about roles. Our role was to come up with a new framework for policy, the policy makers' role was to assess this in salient policy terms and shaped it for policy use. A new language was created through various discussions; principles for transition management were defined as well as story line. Primacy for using the framework clearly lied with policy makers, but they also played an intellectual role in the whole process. In the project, policy makers made us do certain things but on the whole we felt we had a lot of leeway, which we used to push for our ideas. Looking back, it was not the happy consensual process Dutch people are famous for. At the beginning of the project, we ran into a conflict with the project leader Sylvie Warmerdam and were confronted with very critical remarks from Wim Turkenberg (an influential energy scientist) and Peter Aubert, both of which would become key advocates of the approach (as the discussion in the next section shows).

Our conclusion is that the concept of transition served as a boundary concept for scientists and policy makers. We all crossed boundaries and accepted the trespassing by others. We all got something out of it. For policy makers, it was a useful concept which allowed government to orient its innovation policies and energy policies more towards long-term structural change in a co-ordinated manner. VROM wanted to get into energy (being the domain of EZ) and wanted to use the concept for that, whereas for EZ it served multiple aims: creating new business in sustainable energy, be more proactive and be a partner of business on the topic of energy innovation.

\section{Politics of design}

Having described the interactions within the NEPP4 project, we now turn to the politics of (policy) design. Crucial for the support of transition management was that the major advisory councils of the Dutch government advised positively on the concept. Both the RMNO (Nature and Environment Council of the government), the SER (Socio-Economic Advisory Council of the government) and the VROM-Raad (Advisory Council of the Ministry of the Environment) were positive (SER 2001; VROM-Raad 2001; VROM 2003; VROM-Raad and Algemene Energie Raad 2004). When asked about this, Wim 
Turkenburg, influential member of the VROM-Raad at that time recounts how the council came to support transition management:

A strategic choice had to be made: do we adopt the concept or don't we. The first happened, with the argument that sometimes you need new notions or concepts to create a new élan, even when the notion or concept is not unambiguous. Of relevance was that the climate problem (...) was no longer only something for VROM, but also for EZ (...), and that the broad context within which greenhouse gas emission reductions should occur - going beyond the traditional policy domain of VROM could become possible with this approach. (Turkenburg in an email on April 8, 2008)

Here, we see politics of enrolment or instigation (Hoppe 1983) at work, which surrounds policy development. Turkenburg indicates that the transition concept was perceived by him and other members of the Council as an opportunity to enrol EZ in the ecological modernisation process (cf. Smith and Kern 2007). Peter Aubert who became the leader of the transition project at EZ, before Hugo Brouwer was made director of the energy transition, gives us an inside view of what happened within the Ministry of EZ.

The energy transition project gained support within EZ because of multiple motives that appealed to different groups within EZ: sustainable development, innovation, new forms of governance. Transition management held out the promise that it could resolve the innovation-paradox: the failure in the Netherlands to profit from the innovations developed here, because time and again we fail in bringing innovations to the market. At the top-strategic level there was support for transition management, notably secretary-general Jan Willem Oosterwijk, who saw in transition management an interesting and promising new policy approach. A primary condition was that the business community would be visibly involved in the project. (Aubert, in Van der Hoeven 2005, p. 13)

In this statement, Aubert discloses how the transition story line was able to win support from various people and departments in EZ, thus creating a power base. Nevertheless, there was quite some scepticism and resistance within EZ toward adopting a concept from another ministry, VROM. Furthermore, transition management seemed to be at odds with the dominant thinking in terms of further liberalization, privatization and market-based strategies. A niche was created by a few officials, some of which were involved in the NEPP4-process, in the form of a new unit for energy transition management. This unit, called Policy Renewal, consisted of a few people and was led by Aubert. Only when the energy transition process became visible and successful and concrete results were achieved in terms of transition platforms being created, more and more EZ-officials started to see the advantages of the approach.

According to Smith and Kern (2007) a factor for its adoption was that the 'transition storyline' was multi-interpretable, containing something for everyone:

The transitions storyline provided a suite of elements that policy-makers could latch onto. A successful coalition was built because the transitions approach contained considerable interpretative flexibility. Transitions could mean, by turns, long-term envisioning amongst stakeholders, supporting niche innovations, creating new partnerships with business, reducing state involvement, or simply providing a new language for defending existing policy instruments. In terms of coalition formation, the storyline's strength was its susceptibility to deconstruction and co-option. (Smith and Kern 2007, p. 14) 
There is a kernel of truth in that, but, apart from the shadow side that quite some people found the transition storyline unclear, it is not the whole story. As we have shown that there was a lot of resistance from diverse parties, business was not immediately enthused, and there was quite a battle behind the scene about whether or not to accept the concept of transition management. It was a coincidence of factors that made it accepted. The positive power of the concept of transition management and the multi-interpretative capacity of the transition storyline were important factors for garnering support. The support by key players at the top policy level and by influential advisory councils of the government was important too. Other important factors were: the smart manoeuvring of a small group of frontrunners within ministries who created a niche, the need for a new concept in the process of ecological modernization and the need within the ministry of EZ for building up new partnerships with societal parties under different conditions.

\section{Summary and conclusions}

The main purpose of this article was to reflect on our experiences in a project on transitions and transition management for the Dutch government in 2000 in which we worked with policy officials. In this project, we were engaged in a co-production process, the details of which are described in Sects. 3 and 5. The project was successful in that transition management became a key concept for the Ministry of Economic Affairs that also used it to change its relation with business and to have a more active energy innovation agenda aligned with climate policy and business creation goals. In theoretical terms, the project resulted in the creation of a discourse coalition championing a transition story line. When the co-production process was over, the interactions were discontinued, to be resumed 5 years later.

In reconstructing the co-production process, we have tried to find the critical factors that made it a success. To us the critical factors were: first, a strong policy demand and real project to deliver results to policy and second, the use of a discussion format in the project. The discussion format was important for mutual learning and for making the project more policy relevant. Developing a common language proved to be a crucial factor too. The transition language as developed played an important role in our co-production case in acting as a frame. An important facilitating factor was the free, protected environment in which participants feel free to think and speak. Our experience also suggests that scholars involved must not be prescriptive, but need to be open-minded and be open about their own limits of knowledge. As for the policy people, they must be able to step out of their mental framework. The open discussion format helped to do that. Crucial in our project was the willingness to be collectively engaged in the creation of meaning (i.e. going from abstract concepts to empirical evidence and backwards).

The co-production process had a long-term impact: the concept of transition management, the transition language and the new discourse on long-term energy policy, have been used within the policy arena over the last couple of years (under the name of "transition approach"). So, we have shown that contextual opportunities make it possible for scientists and policy makers to co-produce useful knowledge for science and policy. We also showed, however, that it could have gone differently.

Other important spin offs of the co-production process were: better interdepartmental cooperation and direct engagement with the long term energy agenda, as wished by the Ministry of the Environment (VROM), improved relationship with business and direct linkage with the innovation agenda as preferred by the Ministry of Economic Affairs (EZ) 
and the establishment of KSI, the Dutch transition research network as an important outcome for the researchers involved (Rotmans et al. 2003).

Acknowledgements We thank Jan-Peter Voß, Adrian Smith, John Grin, Rob Hoppe and two anonymus reviewers for extensive comments and many helpful suggestions. Their comments helped us to better interpret our experiences in theoretical terms and guided us into a deeper analysis. We also thank Peter Aubert, Frans Vollenbroek and Wim Turkenburg for providing us with detailed representations both in word and writing of what happened.

\section{References}

Caplan, N. (1979). The two communities theory and knowledge utilization. American Behavioral Scientist, $22,459-470$.

Eriksson, J., \& Sundelius, B. (2005). Molding minds that form policy: How to make research useful. International Studies Perspectives, 6(1), 51-71.

Geels, F., \& Kemp, R. (2000). Transities vanuit sociotechnisch perspectief, achtergrondrapport voor de studie "Transities en Transitiemanagement" van ICIS en MERIT ten behoeve van NMP-4. UT, Enschede en MERIT, Maastricht.

Gieryn, T. F. (1983). Boundary work and the demarcation of science from nonscience: Strains and interests in professional ideologies of scientists. American Sociological Review, 48, 781-795.

Gieryn, T. F. (1995). Boundaries of science. In S. Jasanoff, et al. (Eds.), Handbook of science and technology studies (pp. 393-443). Thousand Oaks: SAGE.

Hajer, M. A. (1995). The politics of environmental discourse: ecological modernisation and the policy process. Oxford: Clarendon Press.

Hood, C. (1998). The art of the state. Culture, rhetoric, and public management. Oxford: Clarendon Press.

Hoppe, R. (1983). Economische Zaken schrijft een nota - Een onderzoek naar beleidsontwikkeling en besluitvorming bij nonincrementeel beleid, VU Uitgeverij, Proefschrift VU, Amsterdam.

Hoppe, R. (1999). Policy analysis, science, and politics: from speaking truth to power to making sense together. Science and Public Policy, 26(3), 201-210.

Hoppe, R. (2002). Van flipperkast naar grensverkeer. Veranderende visies op de relatie tussen wetenschap en beleid. AWT-Achtergrondstudie 25, Rotterdam.

Hoppe, R. (2005). Rethinking the science-policy nexus: from knowledge utilization and science technology studies to types of boundary arrangements. Poiesis \& Praxis: International Journal of Technology Assessment and Ethics of Science, 3(3), 199-215.

Jasanoff, S. (1990). The fifth branch: Science-advisors as policymakers. Cambridge: Harvard University Press.

Jasanoff, S. (2004). The idiom of co-production. In S. Jasanoff (Ed.), States of knowledge: The co-production of science and social order (pp. 1-12). New York: Routledge.

Kemp, R., \& Loorbach, D. (2005). Dutch policies to manage the transition to sustainable energy, Jahrbuch Ökologische Ökonomik 4 Innovationen und Nachhaltigkeit (pp. 123-150). Marburg: MetropolisVerlag.

Kemp, R., \& Loorbach, D. (2006). Transition management: A reflexive governance approach. In J.-P. Voss, D. Bauknecht, \& R. Kemp (Eds.), Reflexive governance for sustainable development (pp. 103-130). Cheltenham: Edward Elgar.

Kemp, R., Loorbach, D., \& Loorbach, J. (2007). Transition management as a model for managing processes of co-evolution. The International Journal of Sustainable Development and World Ecology 14, 78-91 (special issue on (co)-evolutionary approach to sustainable development).

Kern, F., \& Smith, A. (2008). Restructuring energy systems for sustainability? Energy transition policy in the Netherlands. Energy Policy, 36, 4093-4103.

KETI. (2000). Van saneren naar innoveren. De rol van kennis en technologische innovaties bij het realiseren van de beleidsopgaven van NMP4. Werkgroep kennis en technologische innovaties (KETI). Nederland: Den Haag.

Loorbach, D. (2007). Transition management. New mode of governance for sustainable development. Utrecht, The Netherlands: International Books.

Loorbach, D., \& Kemp, R. (2008). Transition management for the Dutch energy transition: multilevel governance aspects. In J. van den Bergh \& F. Bruinsma (Eds.), Managing the transition towards renewable energy sources: Theory and practice from local, regional and macro perspectives (pp. 243264). Cheltenham: Edward Elgar. 
Meadowcroft, J. (2005). Environmental political economy, technological transitions and the state. New Political Economy, 10(4), 479-498.

Metze, T. (2007) The power of discursive boundaries in deliberative practices. Paper presented at the conference on Interpretation in policy analysis: Research \& practice, 31 May-2 June 2007, Amsterdam, The Netherlands.

Ministery of Economic Affairs (EZ). (2008). Energy innovation agenda. Den Haag.

Ministry of Economic Affairs (EZ) (2001) De Reis. Transitie naar een duurzame energiehuishouding (The Journey. Transition to a sustainable energy system). Den Haag.

Ministry of Economic Affairs (EZ) (2003a). Plan van aanpak. Project Implementatie Energietransitie fase 2 (Action plan. Project implementation energy transition, phase 2). Den Haag.

Ministry of Economic Affairs (EZ). (2003b). Steering towards the South. Reinvigorating government policy for the energy transition (in Dutch). Advies van het PIT-deelproject Beleidsvernieuwing. Den Haag.

Ministry of Economic Affairs (EZ). (2004). Innovatie in het Energiebeleid. Energietransitie stand van zaken en vervolg, (Innovation in energy policy. State of affairs in the energy transition and follow-up action). Den Haag.

NMP-4. (2001). Een wereld en een wil. Werken aan duurzaamheid (A world and a will. Working towards sustainability). The Hague: SDU.

Pielke, R. (2004). When scientists politicize science: Making sense of controversy over the sceptical environmentalist. Environmental Science \& Policy, 7, 405-417.

Rotmans, J., \& Kemp, R. (2008). Detour ahead. A response to Shove and Walker about the perilous road of transition management. Environment and Planning A, 40, 1006-1014.

Rotmans, J., Kemp, R., van Asselt, M., Geels, F., Verbong, G., \& Molendijk, K. (2000). Transities \& Transitiemanagement. De casus van een emissiearme energievoorziening. Final report of study "Transitions and Transition management" for the 4th National Environmental Policy Plan (NMP-4) of the Netherlands, October 2000. Maastricht: ICIS \& MERIT.

Rotmans, J., Kemp, R., \& van Asselt, M. (2001). More evolution than revolution. Transition management in public policy. Foresight, 3(1), 15-31.

Rotmans, J., Grin, J., \& Schot, J. (2003). Multi-, inter- and transdisciplinary research program into transitions and system innovations. KSI-Research Program, February 2003.

SER (2001) Advies over NMP4 (Advice on National Environmental Policy Plan 4). The Hague, the Netherlands: Social and Economic Council.

Shove, E., \& Walker, G. (2007). CAUTION! transitions ahead: Politics, practice, and sustainable transition management. Environment and Planning A, 39, 763-770.

Smith, A., \& Kern, F. (2007). The transitions discourse in the ecological modernisation of the Netherlands. SPRU electronic working paper series, no. 160.

Smith, A., \& Kern, F. (2009). The transitions story line in Dutch environmental policy. Environmental Politics, 18(1), 78-98.

Star, S. L., \& Griesemer, J. (1989). Institutional ecology, ‘translations' and boundary objects: amateurs and professionals in Berkeley's museum of vertebrate zoology, 1907-1939. Social Studies of Science, 19, 387-420.

Task Force Energietransitie (TFE). (2006). Transitieactieplan "Meer met Energie".

Te Riele, H.R.M., Duifhuizen, S.A.M., Hötte, M., Zijlstra, G., \& Sengers, M.A.G. (2000). Transities: kunnen drie mensen de wereld doen omslaan? VROM-report made by Twijnstra en Gudde.

Van der Hoeven, D. (2005). Symfonie in nieuw gas, SenterNovem, publicatie 8ET-05.03.

Verbong, G. (2000). De Nederlandse overheid en energietransities: een historisch perspectief, achtergrondrapport voor de studie "Transities en Transitiemanagement" van ICIS en MERIT ten behoeve van NMP-4, November 2000, SHT. Eindhoven: TU Eindhoven.

VROM (2003). Nieuwsbrief Transities (Newsletter transitions), nr 3, January 2003.

VROM-Raad. (1998). Transitie naar een koolstofarme energiehuishouding (Transition to a carbon-low energy system). Advies 010. Den Haag.

VROM-Raad. (2001). Waar een wil is is een weg, (Where there's a will, there is a way) advice on NEPP4 (in Dutch). The Hague, The Netherlands: Ministry of Housing.

VROM-Raad en Algemene Energie Raad. (2004). Energietransitie. Klimaat voor nieuwe kansen (Energy transition: climate for new chances (in Dutch). Advice no. 45, The Hague, the Netherlands.

Weingart, P. (1999). Scientific expertise and political accountability: Paradoxes of science in politics. Science and Public Policy, 26(3), 151-161.

Weiss, C. (1980). Social science research and decision-making. New York: Columbia University Press.

Weiss, C. H. (1991). Policy research: Data, ideas, or arguments? In P. E. A. Wagner (Ed.), Social sciences and modern states: national experiments and theoretical crossroads (pp. 307-332). Cambridge: Cambridge University Press. 